\title{
Efekt państwa i dobrostan. Klimat społeczny w odczuciach polskich migrantów w Dublinie
}

\section{Abstract \\ State Effect and Well-being: Social Climate in Impressions of the Polish Migrants in Dublin}

The paper draws on an ethnographic fieldwork among the Polish migrants in Dublin who decided not to return to Poland in a predictable future. I describe the relation of a state effect and wellbeing as a sphere that can be perceived as the social climate by the transnational migrants. The imaginaries and retrospective rationalisations of experiences, feelings and memories connected to a quality of state functioning and a society's openness / oppressiveness impressions create inter-connected space for comparisons of two realities known to the migrants who have left Poland for Ireland over a decade ago, on the eve of their economic self-responsibility, and who are currently justifying their choice to continue their living there.

Keywords: ethnography, social mobility, migration, Ireland, state effect, well-being

Przedmiotem mojego artykułu jest kwestia, jak wyobrażenia na temat państwa przyjmującego i odbiór panującego tam klimatu społecznego wpływają na decyzje tych migrantów z Polski, którzy nie planują powrotu do ojczyzny w dającej się określić perspektywie czasowej. Bohaterowie tego artykułu to pewna, bardzo różnorodna grupa (obecnie w średnim wieku), której przedstawiciele - jako młodzi ludzie u zarania samodzielności ekonomicznej - wyjechała do Irlandii po wejściu Polski do UE, przetrwała tam światowy kryzys gospodarczy i nie wróciła stamtąd po upływie ponad dekady, w trakcie której Polska stała się „zieloną wyspą na morzu kryzysu gospodarczego". 
Postaram się naświetlić część społeczno-kulturowego kontekstu, w jakim podejmowane są decyzje opisywanych tu migrantów z Polski, korzystając z wiedzy zaczerpniętej od przedstawicieli tego pokolenia w trakcie kilkuletnich badań etnograficznych ${ }^{1} \mathrm{w}$ odniesieniu do koncepcji efektu państwa i dobrostanu - zagadnień niewymiernych, które jednak próbuje się mierzyć, a które razem wytwarzają subiektywnie odczuwalny klimat społeczny ${ }^{2}$. Aradhana Sharma i Akhil Gupta słusznie zauważają, że antropologia oferuje szczególnie przydatny obiektyw do badania procesu formacji państwa i do podejmowania prób zrozumienia, jak państwo i jego granice są kulturowo konstruowane. Skupienie się antropologii na poszczególnych odgałęzieniach i poziomach instytucji państwowych umożliwia zdezagregowane spojrzenie na państwo, które pokazuje wielowarstwową, policentryczną i płynną naturę tego zbioru, która zastyga $\mathrm{w}$ różnych sprzecznościach. Projekt antropologiczny dąży do zrozumienia warunków, w których państwo z powodzeniem przedstawia siebie jako spójne i pojedyncze (Sharma, Gupta 2006: 9-10). Jak pokazuję w tym artykule, tworzenie wizerunku państwa nie musi polegać na nadczynności w wykonaniu regulacyjnych i prawodawczych instytucji państwa oraz jego służb, a doceniana jest atmosfera przewidywalności i stabilizacji, która pomaga rozwijać osobiste plany i strategie oraz przekłada się na odczuwanie dobrostanu. W przypadku opisywanych tu osób pochodzących z Polski i zamieszkałych w Irlandii efekt państwa opiera się na wytworzonym klimacie, na odczuwanym przez ludzi funkcjonujących w tym systemie wrażeniu, że to właśnie państwo jest adresatem pochwał i zażaleń.

Efekt państwa - w oryginalnej propozycji sformułowanej przez Timothy'ego Mitchella (1999) dla teoretyków państwa - jest wytwarzany w gąszczu przyziemnych procesów organizacji czasoprzestrzennej, specyfikacji funkcjonalnych, nadzoru i inwigilacji oraz reprezentacji, które sprawiają, że świat jawi się jako zasadniczo podzielony na państwo i społeczeństwo lub państwo i gospodarkę. Istotą współczesnej polityki jest wytwarzanie i reprodukcja tych linii różnic (Mitchell 1999: 95). Na potrzeby tego opracowania zdefiniuję efekt państwa jako wpływ odbioru wytwarzanego w ten sposób klimatu państwa przez osoby w nim mieszkające na jakość odczuwania przez nie dobrostanu. Interpretuję efekt państwa przede wszystkim jako zbiór wyobrażeń - w tym przypadku obecny w narracjach części polskich migrantów w Dublinie - na temat państwa i jakości życia

1 Projekt badawczy NCN nr UMO-2014/13/B/HS3/04927, pt. „Polacy sukcesu - między emigracją a transnarodowością. Nowe oblicze polskiej diaspory w Europie Zachodniej” pod kierownictwem prof. dra hab. Aleksandra Posern-Zielińskiego.

2 Słowo „klimat” rozumiem jako występujący na określonym obszarze zespół czynników, które wpływają na badaną sferę rzeczywistości w wyznaczonym okresie. Słowo to występuje w szeregu zastosowań, zwłaszcza w meteorologii, a także w ekonomii (np. „klimat inwestycyjny”; zob. Khan 2005: 77) czy w naukach politycznych. Celowo nie używam tu słowa „kultura”, choć mam świadomość, że to o niej piszę. Klimat jest pojęciem, które w metaforyczny sposób lepiej oddaje dynamikę recepcji zjawisk społecznokulturowych (w tym gospodarczych i politycznych), które tworzą kontekst moich rozważań. 
w nim: sprawności jego funkcjonowania, przyjazności, otwartości i umożliwiania integracji, opresyjności, regulowania relacji społecznych i interpersonalnych, zapewniania poczucia dobrostanu i tworzenia wizerunku, który wpływa na odczucie, czy dane państwo jest dobrym miejscem do życia. Efekt ten jest wytwarzany zarówno przez działanie instytucji państwa i przez nie regulowanych, jak i przez odczucia wywoływane przez zachowania obywateli i innych osób zamieszkujących jego terytorium. Przenikanie się tych sfer w kulturze publicznej i popularnej oraz $\mathrm{w}$ życiu codziennym na poziomie lokalnym wpływa na subiektywną ocenę „klimatu” państwa i społeczeństwa, a perspektywa porównawcza migrantów, których cechuje transnarodowość o stosunkowo wysokiej dynamice uczestnictwa w ich środowiskach w Polsce i w Irlandii, powoduje, że jednoczesnej ocenie każdorazowo podlegają państwa i społeczeństwa obu krajów.

Dobrostan, którego sposób odczuwania jest w tym ujęciu najistotniejszy dla postrzegania klimatu państwa i społeczeństwa, jest jednym z czynników, które niezwykle trudno zmierzyć ze względu na subiektywność i relacyjność odczuć z nim związanych. Pomimo to odgrywa coraz większą rolę w zestawieniach statystycznych sporządzanych na potrzeby administracji rządowych i organizacji międzypaństwowych (Bank Światowy, ONZ, Światowa Organizacja Zdrowia). Występuje tam jako „wskaźnik satysfakcji życiowej” czy „wskaźnik godnego życia”’.

Dobrostan jest jedną z kategorii analizy jakości życia w państwach narodach od co najmniej 1948 roku, kiedy to został ujęty w art. 25 Powszechnej Deklaracji Praw Człowieka ${ }^{4}$. Tłumacząc rosnącą popularność tej kategorii w naukach spo-

3 Jest to pojęcie, które do języka nauk społecznych przedostało się zapewne z nauk medycznych. Mówiono o „dobrostanie pacjenta” czy „ogólnym dobrostanie pacjenta”, mając na uwadze integralność psychiczną i fizyczną osoby, w którym to ujęciu im mniej deficytów stwierdzono, tym bliżej była ona ideału zdrowia psychofizycznego. Pojęcie dobrostanu zaadaptowano także w psychologii rozwojowej i psychologii osobowości, gdzie dobrostan stanowi punkt odniesienia dla analiz dotyczących wpływu zmiennych biograficznych na psychikę. Pojęcie to uległo naturalizacji i doczekało się popularyzacji w psychologicznych modelach dobrostanu (np. Edwarda F. Dienera, Carol Ryff czy Martina Seligmana, promotora positive psychology) uwzględniających różne aspekty życia, których jakość ma wpływ na dobrostan postrzegany jako rodzaj ideału życiowego analizowanego w kategoriach filozoficzno-społecznych i emocjonalnych. W ostatnich jednak dekadach dobrostan robi zawrotną karierę w naukach ekonomicznych, studiach nad rozwojem i postrozwojem, w psychologii międzykulturowej i wielu obszarach interdyscyplinarnych studiów społecznopolitycznych, a także w socjologii oraz w antropologii kulturowej. W tych dziedzinach dobrostan ludzki (human well-being) odnosi się do „stanu bycia z innymi, gdzie ludzkie potrzeby są zaspokajane, gdzie można działać w sposób znaczący, aby realizować swoje cele i gdzie dana osoba cieszy się zadowalającą jakością życia” (Gough i in. 2007: 34).

4 „Każdy człowiek ma prawo do stopy życiowej zapewniającej zdrowie i dobrobyt [dobrostan] jego i jego rodziny, włączając w to wyżywienie, odzież, mieszkanie, opiekę lekarską i konieczne świadczenia socjalne oraz prawo do ubezpieczenia na wypadek bezrobocia, choroby, niezdolności do pracy, wdowieństwa, starości lub utraty środków do życia w inny sposób od niego niezależny", Powszechna Deklaracja Praw Człowieka, art. 25, pkt 1, http://www.unesco.pl/fileadmin/user_upload/ pdf/Powszechna_Deklaracja_Praw_Czlowieka.pdf (dostęp: 18.01.2020). W tłumaczeniu na język 
łecznych, Katie Wright (2012) analizuje, że w badaniach nad rozwojem pojawiły się próby konceptualnego przejścia od koncentracji na rozwoju gospodarczym do skupienia się na tym, co „sprawia, że warto żyć”. Jej zdaniem:

[p]odczas gdy dominujący nurt dyskursu rozwojowego i migracyjnego wciąż skupiał się na lukach i deficytach dóbr materialnych, kładąc nacisk na to, czego brakuje biednym ludziom lub migrantom o niskich dochodach, to nowe konceptualizacje rozwoju poszły w kierunku szerszych rozważań nad tym, co owe grupy cenią. Podobnej zmianie uległy również podejścia do dobrostanu człowieka, które obecnie pomagają skupić uwagę na tym, co ludzie mają i jak myślą oraz co myślą o tym, czym mogą być i co robią (Wright 2012: 2).

Autorzy omawiający znaczenie terminu „dobrostan” (np. Corsín Jiménez 2007; Wright 2012; Fischer 2014; Bache, Scott 2018) wskazują, że do najpowszechniejszych sposobów jego dookreślania należą „jakość życia” „satysfakcja życiowa” oraz „szczęście”. Potwierdza to przegląd polskich prac na temat dobrostanu, które dość schematycznie odsyłają do pracy Janusza Czapińskiego Psychologia szczęścia (1992).

Mój tekst jest rezultatem badań terenowych prowadzonych w Dublinie i okolicach w formie kilkumiesięcznych pobytów w latach 2015-2017 i kontynuowanych w postaci krótszych wyjazdów do chwili obecnej. W związku z pracą na uniwersytecie moje pobyty w Irlandii w latach 2015-2017 przypadały na miesiące letnie, między lipcem a wrześniem. Pobyty późniejsze miały natomiast charakter jedno-, dwutygodniowych wizyt badawczych, w trakcie których odwiedzałem partnerów badawczych i osoby poznane w trakcie realizacji projektu NCN, sporadycznie nawiązując i eksplorując nowe kontakty.

Prowadząc swoje badania, postanowiłem eksplorować teren przez wykorzystanie i rozbudowywanie własnej sieci krewnych i znajomych, którzy wyjechali do Irlandii. Taka pośredniczona sieciowo etnografia migracji (por. Kaczmarek 2017) była dla mnie tym bardziej dogodna, że większość osób, które zdecydowały się wyjechać do Irlandii po 2004 roku, należała do podobnego pokolenia i urodziła się w latach 70. lub 80. XX wieku. Wyjechały one po uzyskaniu w Polsce wykształcenia, znajdując się na początku XXI wieku dopiero na początku samodzielności życiowej. Jeśli nawet osoba należąca do tej generacji nie posiadała doświadczenia migracyjnego, to $\mathrm{z}$ dużym prawdopodobieństwem ona sama lub ktoś z sieci jej znajomych albo krewnych znał osoby, które wyjechały zwłaszcza do krajów, gdzie można żyć, posługując się językiem angielskim. Ponieważ sam należę do takich osób, postanowiłem to wykorzystać w celu praktykowania etnografii i wśród migrantów w Dublinie ${ }^{5}$.

polski wkradł się oczywiście błąd, gdyż „well-being” przetłumaczono nie jako „dobrostan”, a jako „dobrobyt”, co nadmiernie uwypukla aspekt ekonomiczny, podczas gdy chodziło o godne życie niezależnie od kondycji gospodarczej.

${ }^{5}$ Stanowi to wyjaśnienie powodów, dla których w zasadzie nie omawiam sytuacji pracowników wielkich korporacji międzynarodowych, którzy de facto nie pojawiają się w zasięgu sieci migracyjnych rozwijanych przez osoby, do których dotarłem, stosując swoje metody. Ci pracownicy korpo- 
Uzupełniająco posługiwałem się w moich badaniach tradycyjną, etnograficzną metodą wydeptywania ścieżek. Gdy natrafiałem na informacje, że w jakimś miejscu można spotkać Polaków, którzy tam już osiedli (np. w placówkach służby zdrowia, na stanowiskach administracyjnych w firmach czy na uniwersytetach, w kancelariach prawniczych itp.), udawałem się tam, by się przedstawić i zaprosić chętne osoby do rozmów ze mną. Wiele osób odmawiało, zwłaszcza takich, które dały się już kiedyś namówić do udziału w źle prowadzonych badaniach socjologicznych, i oświadczały, że szkoda im czasu i energii na odpowiadanie na zbyt szczegółowe i nudne pytania. Prawie zawsze jednak spotykałem osoby, które uważały, że mogą opowiedzieć coś interesującego, co może się okazać ważne dla zrozumienia sytuacji ich i wielu migrantów w Irlandii. Często osoby te zapraszały mnie do domów, gdzie miałem okazję poznać członków ich rodzin czy partnerów, lub umawiały się ze mną w czasie wolnym czy na lunch.

Zastosowane metody $\mathrm{z}$ oczywistych względów nie pozwalają dotrzeć do wszystkich migrantów polskich w Dublinie i okolicach, ani równomiernie zbadać ich sytuację. Ich zadaniem jest umożliwienie uzmysłowienia sobie szerokiego kontekstu badanych zjawisk, a w tym zmiennych czynników wpływających na indywidualne odczucia, poglądy i praktyki osób, z którymi udało mi się nawiązać satysfakcjonujący kontakt. Staram się następnie przedstawić moje refleksje i obserwacje, na które wpływ ma, co oczywiste, moja wiedza uzupełniana lekturą szerokiej literatury tematu ${ }^{6}$ i zestawień statystycznych, a także doświadczenia wynikające z mojej percepcji rzeczywistości zdeterminowanej przez wykonywany zawód, moje przeżycia i tereny badawcze.

racji, którzy zostali zrekrutowani w Polsce albo w innych krajach, w większości byli przygotowani do migracji do centrali lub na Zachód, co stanowiło rodzaj uznania dla ich kwalifikacji i osiągnięć zawodowych czy też stało się kolejnym etapem kariery. Ich wyjazdy były zazwyczaj starannie zaplanowane i przygotowane, a sieć migracyjną w ich przypadku stanowiły instytucje wykorzystywane przez ich firmy do organizacji pobytu pracowników w miejscu, gdzie mieli świadczyć efektywną pracę. W wielu przypadkach można porównać ich sytuację do mobilnych profesjonalistów opisywanych przez Meike Fechter w artykule pt. Living in a Bubble: Expatriate's Transnational Spaces (2007). Z podobnych względów moje analizy nie obejmują pracowników polskich instytucji państwowych skierowanych do Irlandii. Niemniej nawiązałem pewne kontakty z przedstawicielami wspomnianych tu środowisk, gdyż ich opinie i obserwacje są dla mnie pomocne do rozpatrywania sytuacji grupy, która zajmuje mnie w moich irlandzkich badaniach najbardziej - ludzi, którzy docierali do Irlandii na własną rękę.

${ }_{6}$ Polska migracja do Republiki Irlandii nie doczekała się jeszcze wielu publikacji opartych na badaniach etnograficznych. W dorobku nauk społecznych dominują omówienia oparte na analizie ogólnodostępnych danych statystycznych, takich jak irlandzkie spisy powszechne (Kloc-Nowak 2017) czy materiały polskiej Państwowej Komisji Wyborczej (np. Lesińska 2017; Lesińska, Kloc-Nowak, Pszczółkowska 2019). Dostępne są również raporty z prowadzonych badań surveyowych (np. Mühlau, Kaliszewska, Röder 2011). 


\section{Klimat społeczny Irlandii}

Tamar D. Wilson (1994) wskazała, że migranci zarobkowi (labor migrants) szukają pracy i jadą przede wszystkim tam, gdzie mają krewnych lub przyjaciół i nazwała to "migracją pośredniczoną sieciowo" (network-mediated migration). Odnosi się to, co do zasady, także do dominującej w moich badaniach pierwszej masowej fali migracji z Polski do Irlandii, która dotarła tam po rozszerzeniu Unii Europejskiej w 2004 roku. Trzeba jednak zaznaczyć, że ścieżka migracyjna stosunkowo wielu tworzących ją początkowo osób stanowi odstępstwo od sformułowanej przez Wilson reguły. Przedstawiciele tej forpoczty, którzy przybywali jeszcze przed wejściem Polski do UE (lub niedługo po tym wydarzeniu) najczęściej nie dysponowali rozbudowanymi sieciami w społeczeństwie przyjmującym. Również w latach późniejszych część osób przyjeżdżała z Polski w ciemno, często bez znajomości miejscowego języka, zdając się na nawiązywanie kontaktów na miejscu. Ci, którzy choć trochę znali język, radzili sobie dzięki specyficznej gotowości irlandzkich pracodawców do przyjmowania do pracy migrantów, którzy w latach 2004-2010 - jeśli chodzi o Polaków, a także na przykład Litwinów, Słowaków czy Czechów - w większości byli młodymi ludźmi między 20. a 30. rokiem życia.

Tym, co ich tam przyciągnęło, w narracjach większości z nich, były informacje o panującym klimacie społecznym - o sprawnym państwie, które po rozszerzeniu UE zniosło obowiązek pozwoleń na pracę dla nowych obywateli Unii; państwie zamieszkiwanym przez sympatyczne, otwarte społeczeństwo, gdzie można zarobić i doszlifować angielski. Media informowały wówczas o „celtyckim tygrysie” (zob. Coulter, Coleman 2003), kraju w którym średnie zarobki wyprzedziły Wielką Brytanię i gdzie było bardzo duże zapotrzebowanie na zagranicznych pracowników. Irlandia była w Polsce darzona sympatią, choć znana głównie „z pozytywnego przekazu na temat dnia świętego Patryka i fajnej muzyki, no i podobna historia, też byli okupowani, wyzwolili się, i katolicy". W wypowiedziach kilkorga spośród tych „pionierów” to właśnie „klimat tego państwa (nie myślę o pogodzie, choć też się można przyzwyczaić)" powodował, że de facto niewiele wiedząc na temat tego kraju, decydowali się na „podróż w nieznane” (choć jedna z osób wyraziła do dosadniej, mówiąc: „Przyjechałem tu na pałę, głupi byłem, ale się udało”7).

Piotr, absolwent politologii, obecnie ok. 40 lat, na wyjazd zdecydował się wiosną 2005 pod wpływem frustracji w pracy przy projektach w samorządzie terytorialnym, w której mu zakomunikowano, że pomimo dobrych wyników „są nikłe szanse, by go zatrudnić na stałe”, gdyż nie chciał się zapisać do pewnej partii. Wziął urlop i poleciał tanią linią lotniczą do Dublina, gdzie nikogo nie znał. Przez kilkanaście dni mieszkał w hostelu i chodził od miejsca do miejsca, pytając o pracę fizyczną wymagającą podstawowej znajomości angielskiego, choć, jak twierdzi, dobrze sobie z tym językiem radził. Pierwszą pracę znalazł po około tygodniu, Zaczynał od sprzątania sklepów i magazynów, później przeprowadził się do współdzielonego mieszkania z wi-fi, skąd szukał kolejnych ogłoszeń. Opowiada, że na początku bardzo pomógł mu system cotygodniowych wypłat, dzięki czemu nie musiał się mocno zadłużać. Twierdzi, że nigdy nie spotkał się z otwartą dyskryminacją, 
Wśród kilkudziesięciu osób, z którymi prowadziłem rozmowy, tylko kilkoro zgłębia najnowszą historię społecznopolityczną nowego kraju i miejscowości, w których żyją. Są także takie, które angażują się w różne akcje społeczne związane $\mathrm{z}$ obchodami ważnych rocznic $\mathrm{w}$ historii Irlandii tudzież w irlandzkie kampanie referendalne oraz działania organizacji pozarządowych działających na rzecz praw mniejszości i LGBT czy zwalczających wykluczenia i ubóstwo.

Te, relatywnie nieliczne, osoby, które bliżej interesują się krajową, irlandzką polityką, wiele się dowiadują $\mathrm{z}$ artykułów prasowych i mediów dostępnych $\mathrm{w}$ internecie, niektóre aktywnie działają na portalach społecznościowych w językach angielskim i polskim. Telewizję oglądają nieliczni. Migranci z grupy, z którą prowadziłem badania, wiedzą dużo o tematach życiowych i wśród moich rozmówców sporo osób głosuje $\mathrm{w}$ wyborach samorządowych, do czego mają prawo jako zarejestrowani rezydenci Irlandii, niezależnie od narodowości. Jednakże w natłoku zajęć zawodowych i prywatnych większość osób śledzi informacje pobieżnie i nie wnika w tematy, które ich nie dotyczą bezpośrednio.

Na tle irlandzkiej, bieżącej polityki krajowej (partyjnej), z którą czują niewielki związek, wyjątek stanowią aspekty światopoglądowe, związane z gorącymi, odbywającymi się dość regularnie debatami publicznymi towarzyszącymi irlandzkim kampaniom referendalnym w sprawie związków partnerskich (w tym jednopłciowych) i prawa do aborcji. W tych aspektach prawie każda z osób, z którymi rozmawiałem, miała określone stanowisko.

Już w roku 2010 w Irlandii zezwolono na związki partnerskie osób o tej samej płci, a w 2013 komisja do spraw reformy konstytucyjnej rekomendowała wprowadzenie $\mathrm{w}$ konstytucji zmian $\mathrm{w}$ celu zalegalizowania równoprawnych małżeństw homoseksualnych. W referendum przeprowadzonym w maju 2015 roku ponad $62 \%$ głosujących wsparło ten projekt. Z kolei referendum z 25 maja 2018 roku doprowadziło do dużej liberalizacji należących dotąd do najostrzejszych w Europie przepisów antyaborcyjnych. Większość migrantów z Polski, z którymi o tym rozmawiałem, przyznaje, że wskutek tych decyzji Irlandia stała się krajem jeszcze bardziej otwartym, liberalnym i demokratycznym. Nawet jeśli części osób początkowo nie obchodziło, jaki będzie wynik tych głosowań, to po ogłoszeniu wyników niektórzy czuli „coś w rodzaju dumy, że ich nowy kraj dołączył również pod tym względem do światowej czołówki”. Ela, która to wyraziła, opowiadała, że początkowo nawet się cieszyła, że nie ma prawa wyborczego, bo adoptowanie dzieci przez pary jednopłciowe to było dla niej „zbyt wiele”, jednak z każdym kolejnym głosowaniem znoszącym dyskryminację na tle obyczajowym czy

a wręcz przeciwnie, na Irlandczykach dobre wrażenie robiło, że się umi[ał] dogadać i że można było z nim [było z nim] normalnie porozmawiać. Przyzwyczaił się do pracy fizycznej, ale korzystając z programów szkoleniowych organizowanych przez pracodawców, związki zawodowe i państwo, za które często musiał sam płacić, wyrobił sobie specjalistyczne certyfikaty zawodowe, dzięki którym obecnie zarabia co najmniej 1000 EUR tygodniowo, obsługując wysokiej klasy sprzęt mechaniczny w stoczni. 
światopoglądowym i podnoszącym pozycję kobiet wobec prawa coraz bardziej żałuje, że nie mogła się do tego przyczynić. Kilka z poznanych przeze mnie w Dublinie osób wzięło udział w kampaniach przedreferendalnych na rzecz liberalizacji przepisów, roznosząc ulotki lub pracując przy organizacji spotkań oraz uczestnicząc w manifestacjach.

Większość z moich rozmówców wyraziła żal, że w tym zakresie „Polska ma jeszcze wiele do nadrobienia, by dogonić Zachód”. Z ich opowiadań na temat różnic w ich życiu przed i po imigracji wynika również, że tylko nieliczni, i to sporadycznie, biorą udział w publicznych praktykach religijnych, gdyż w Irlandii nie czują ku temu presji społecznej - w tej kwestii można wysnuć wniosek, że w grupie, z którą prowadziłem badania, po przyjeździe do Irlandii spadła częstotliwość praktyk religijnych u tych osób, które brały w nich udział w Polsce. Część osób nie uczestniczyła $\mathrm{w}$ życiu religijnym $\mathrm{z}$ różnych względów już $\mathrm{w}$ Polsce bądź też zaprzestała praktyk religijnych po emigracji. Te natomiast, które praktykowały, często wybierały do uczestnictwa w zwykłych mszach lokalne, katolickie kościoły irlandzkie, gdyż - jak mówiły - „są one o wiele bardziej przyjazne i partnerskie, a wiernych traktuje się z szacunkiem, księża zaś nie mówią tam o polityce i nie domagają się pieniędzy". Interesujące jest, że opinie moich rozmówców odnosiły się do dwóch aspektów: $\mathrm{z}$ jednej strony dotyczyły porównania wrażeń wyniesionych z kontaktów z Kościołami polskim i irlandzkim, a z drugiej - oceny różnic w pracy kościołów w Irlandii prowadzonych przez księży Polakówi Irlandczyków.

Inne zagadnienie to dojazd do kościołów, gdzie mieszczą się polskie duszpasterstwa lub są odprawiane polskojęzyczne nabożeństwa, który jest dla wielu osób czasochłonny, co również przyczynia się do spadku częstotliwości wizyt w tych „polskich” placówkach i decyzji o wyborze kościołów lokalnych lub prowadzi do stopniowej rezygnacji z religijnych praktyk publicznych. Kilka spośród poznanych przeze mnie osób brało ślub w polskim kościele lub ich dzieci otrzymywały tam chrzest lub przystępowały do komunii. Dokonywano wyboru polskiego kościoła mimo świadomości, że „z Irlandczykami łatwiej byłoby załatwić papiery, bo bardziej ufają człowiekowi”, ale (w przypadku komunii) „to jednak były właściwie tylko polskie dzieci i przyjechali dziadkowie". Opinie o funkcjonowaniu Kościoła w Irlandii w zależności, czy duszpasterstwa prowadzą księża polscy, czy inni, są zróżnicowane i zależne od indywidualnych doświadczeń poszczególnych osób. Niektórzy z moich rozmówców zwracali uwagę, że atmosfera posługi oferowanej przez dominikanów różni się korzystnie od tej, którą świadczą chrystusowcy w najstarszej polskiej parafii, gdyż ci pierwsi podchodzą do swych relacji z wiernymi w sposób mniej sformalizowany i bardziej partnerski. Inne osoby były zdania, że jednak to u św. Audoena (w parafii prowadzonej przez chrystusowców) jest „bardziej polsko w nastroju” i dlatego to tam chodzą na msze wielkanocne czy bożonarodzeniowe. Moi rozmówcy - niezależnie, czy w Polsce praktykowali, czy też nie - wyrażają zgodną opinię, że Kościół był w Polsce istotną siłą polityczną, kształtującą klimat społeczny oraz ważnym medium rozprzestrzeniania i kształ- 
towania opinii publicznej. Niektórzy wprost oskarżali Kościół w Polsce o przeciwdziałanie zmianom społecznym i obyczajowym, które mogłyby poprawić atmosferę życia społecznego i politycznego oraz uczynić kraj bardziej otwartym i przyjaznym do życia. Wszystkie osoby, z którymi rozmawiałem na ten temat, a także te, które nie wyraziły takich opinii, akcentowały, że w porównaniu z Polską rola Kościoła katolickiego w Irlandii w życiu politycznym i społecznym jest zdecydowanie mniejsza. Niektóre osoby tłumaczyły, że zdają sobie sprawę, że irlandzki Kościół jest wciąż potężny i wszechobecny (np. prowadzi większość szkół), ale po skandalach pedofilskich i innych aferach ostatnich dekad zachowuje większy dystans i nie angażuje się w życie społeczne, jak to miało miejsce przez poprzednie stulecie walki o niepodległość i budowania suwerennej Republiki.

Osobną kwestią w tej relatywnie otwartej światopoglądowo grupie, z którą prowadziłem badania, jest stosunek do migracji z państw innych niż Polska, który rzutuje na interpretacje stanu społeczeństwa irlandzkiego, zwłaszcza w najludniejszym mieście nowego kraju. $\mathrm{Z}$ jednej strony polscy migranci wyrażają aprobatę dla otwartości społeczeństwa Irlandii na migracje, dzięki której sami szybko poczuli się dość dobrze w nowym kraju, z drugiej zaś część moich rozmówców mniej lub bardziej bezpośrednio przyznaje się do stosowania gradacji „swojskości” i „przydatności” przybyszów dla społeczeństwa przyjmującego (Kaczmarek 2012), w której przyjmują kryteria historycystyczne i kulturalistyczne, w pewnych wypowiedziach zahaczające o rasizm. Ludzie podlegali $\mathrm{w}$ tych wypowiedziach ocenie na podstawie tego, $\mathrm{z}$ jakiego kraju pochodzą, i wyznawanej religii, przy czym biegun wartościowania był tożsamy z opisywanym wiele lat wcześniej przez Saida w jego Orientalizmie (1991).

Opinie takie pojawiały się w wypowiedziach licznych osób, gdy poruszaliśmy problematykę „kryzysu migracyjnego i uchodźczego”, oraz gdy opowiadały, z kim pracują, do jakiej szkoły chodzą ich dzieci, jak się żyje w Dublinie w porównaniu $\mathrm{z}$ innymi miejscami, które polscy migranci znają z doświadczenia. Moje badania w Irlandii rozpoczęły się w okresie kampanii wyborczej do polskiego parlamentu w roku 2015. Cechowała się ona bezprecedensową ilością informacji związanych $\mathrm{z}$ nasileniem się fali migracji do Europy, które spowodowane były wojną domową w Syrii oraz polityką państw, z których biegną „kanały migracyjne”. Sytuacja ta została wykorzystana w kampanii wyborczej w Polsce do prezentowania części (de facto większości) biorących w niej udział ugrupowań jako tych, które obronią polskie społeczeństwo przed „zagrożeniem” ze strony niechrześcijańskich czy „obcych kulturowo" migrantów. Wielu użytkowników portali społecznościowych oraz prawicowe media przedstawiały przymusowych migrantów z krajów muzułmańskich jako migrantów ekonomicznych, najeźdźców czy wręcz ukrytych terrorystów (zob. też Jaskułowski 2019: 36 i nast.). 


\section{Ku społeczeństwu otwartemu}

Omawiając otwartość irlandzkiego społeczeństwa i państwa, wielu z moich rozmówców zwraca uwagę na uprzejmość, życzliwość i szacunek okazywany zazwyczaj w Irlandii przybyszom $\mathrm{z}$ naszej części Europy na poziomie formalnym: w pracy, w sklepie, na ulicy. Część osób uważa jednak, że jest to powierzchowna i wyuczona „poprawność polityczna”, która w życiu codziennym jest dość przyjemna, ale maskuje fakt, że migrantom jest trudniej wspiąć się w irlandzkiej hierarchii społecznej, jeśli nie nawiążą relacji zażyłości, a najlepiej rodzinnych z rdzennymi Irlandczykami. Jeden z moich przyjaciól, Wojtek, który śmieje się, że jemu jest łatwiej krytykować, bo karierę robi jego żona, a on tu „tylko sprząta”, twierdzi wręcz, że dopiero ich dzieci będą miały poczucie, że to ich kraj, a raczej miasto, a i tak będą się zdarzać tacy „miejscowi”, którzy będą im wypominać obce pochodzenie, choćby z racji nazwiska albo braku wspólnych dalekich ciotek na odległej prowincji.

Warto podkreślić, że osiągnięcie atmosfery formalnej życzliwości wymagało wiele pracy, którą włożono w konsekwentne redukowanie w dyskursie kultury publicznej postaw dyskryminacyjnych wobec odmienności kulturowych i w wykreowanie pozytywnego wizerunku państwa i klimatu społecznego wobec imigrantów w Irlandii, która do Wspólnot Europejskich (WE) weszła dopiero w latach 70. $\mathrm{XX}$ wieku, w 80. stała się państwem przyjmującym migrantów, a w kolejnej dekadzie zaczęła być postrzegana jako kraj dużego sukcesu gospodarczego. Wysiłki te nie dotyczyły wszakże jedynie otwartości wobec odmienności, a były nakierowane na wprowadzenie społeczeństwa irlandzkiego w nowy etap nowoczesności, cechujący się gwałtowną transformacją społeczno-ekonomiczną i „europeizacją” (por. Wilson, Donnan 2006: 10, 137-162) stymulowaną wejściem do UE. Thomas M. Wilson i Hastings Donnan podkreślają wielkie znaczenie nowych form zarządzania poprzez dialog i konsultacje społeczne oraz społeczne partnerstwo, które były postrzegane jako

[...] ciekawa, lecz ważna mieszanka domorosłych irlandzkich (ale też brytyjskich i północnoirlandzkich), stymulowanych również przez europejskie wartości sprawiedliwości społecznej i praworządności, rozwiązań dla problemów podziałów społecznych i peryferyjności ekonomicznej (Wilson, Donnan 2006: 11).

8 Wojtek, 40 lat, w Irlandii od lat 12, cały czas w tym samym miejscu pracy, jako sprzątacz w prywatnej firmie prowadzonej przez i zatrudniającej migrantów, awansuje w hierarchii wewnętrznej swojej firmy, nie ruszając się z obsługiwanego miejsca. Zaczynał jako zwykły sprzątacz i po latach został szefem ekipy działającej w dwóch skrzydłach szpitala. Iza, jego żona, w tym czasie kilkakrotnie się przekwalifikowywała i została specjalistką w pomocy dentystycznej. Obecnie posiada najwyższe wymagane irlandzkim prawem uprawnienia $\mathrm{w}$ swoim zawodzie oraz pozycję profesjonalistki, „pozwalającą na stawianie warunków” pracodawcom, co jednak wcześniej wymagało kilkukrotnego składania wypowiedzeń i podejmowania ryzyka rozpoczynania pracy w zespole u nowego pracodawcy. 
W tym samym czasie w Irlandii trwa ostra debata nad pozornością odniesionego sukcesu wobec głębokich nierówności społecznych i pojawianiu się nowych form zależności wobec globalnego (zwłaszcza amerykańskiego) kapitału oraz dotykających licznych grup społecznych wykluczeń w sferze mieszkaniowej, edukacyjnej i na rynku pracy (Kuhling, Keohane 2007: 17), pogłębionych przez głęboki kryzys, który symbolicznie (i tymczasowo) uśmiercił Celtyckiego Tygrysa na przełomie pierwszej i drugiej dekady obecnego milenium (Coen, Maguire 2012).

W książce Immigration and Social Cohesion in the Republic of Ireland Bryan Fanning (2011) opisuje premedytację, z jaką dążono do wypromowania odpowiedniego klimatu dla imigracji i integracji społecznej kosztem odejścia od „etnokulturowych zasad przynależności”, jakie dominowały w dyskursie kultury publicznej od zarania irlandzkiej państwowości w celu wytworzenia stabilnej perspektywy rozwoju gospodarczego. Analizuje w niej, między innymi, celowe przemiany $\mathrm{w}$ instytucjonalnych narracjach dotyczących przynależności społecznej (belonging). Przyjmuje, że do powstania trwałego klimatu społecznej otwartości wobec migrantów przyczyniło się wykreowanie i promocja „rozwojowych zasad przynależności”, których ewolucję można śledzić poprzez analizę raportów o stanie państwa. Fanning przywołuje wybrane dokumenty. Rozpoczyna od raportu State Development z 1958 roku, którego ukazanie się poprzedziły badania naukowe dotyczące relacji gospodarczych, również z uwzględnieniem emigracji, po uzyskaniu przez Irlandię niepodległości (Fanning 2011: 17, 32). Z kolei we wspólnym raporcie rządu Irlandii i OECD, zatytułowanym Investment in Education (1965), nakreślono program zmian oświaty, dotąd dość mocno nakierowanej na formację religijną, w stronę rozwoju kapitału ludzkiego, tak aby sprostać wyzwaniom industrializującej się gospodarki. Doniosłość rozwojowych zasad przynależności jest widoczna na przykładzie raportu irlandzkiego National Economic and Social Council z 2005 roku Developmental Welfare State. Nacisk rozwojowy położono w nim na „zrównoważoną równowagę między dynamiką a bezpieczeństwem”: prawo wyboru, indywidualną autonomię, zwiększanie szans indywidualnych, zapewnianie warunków społecznych, które wspierałyby i podtrzymywały indywidualne zdolności adaptacyjne, elastyczność i podejmowanie ryzyka (Fanning 2011: 17-18).

Co istotne, Fanning, odnosząc się do swojej wcześniejszej książki Racism and Social Change in the Republic of Ireland (2012 [2002] $\left.{ }^{9}\right)$, opisuje szeroki kontekst, w którym liberalna, modernizacyjna ideologia rynku i społecznej integracji miała się przysłużyć tworzeniu nowego narodu irlandzkiego w oderwaniu od głęboko zakorzenionych w historii tradycyjnych antypatii w społeczeństwie irlandzkim. Owe resentymenty pomiędzy dominującą liczebnie, a po odzyskaniu niepodległości także politycznie, grupą irlandzkich katolików a rdzennymi protestantami, Żydami i Travellersami, miały istotne znaczenie w okresie, gdy Irlandia nie do-

9 W tym artykule posługuję się uzupełnionym wznowieniem tej książki z 2012 roku. 
świadczała masowej imigracji, a wręcz przeciwnie, jej ludność sama tworzyła tak zwane społeczeństwo emigracyjne. Autoafirmacyjny, nakierowany na supremację irlandzkich katolików dyskurs narodotwórczy ukształtowany w pierwszych dekadach po odzyskaniu niepodległości wyciszał przekazy o tym, że Irlandczycy, z ich historią kolonialnej opresji i wymuszonej masowej emigracji, mogli być w swoim czasie zdolni do brutalnego, dyskryminacyjnego traktowania innych. Wszelkie wzmianki o tego rodzaju wydarzeniach z przeszłości spotykały się z gwałtownymi protestami „ludzi emocjonalnie związanych $\mathrm{z}$ autoafirmatywnymi narracjami wspólnotowymi” (Dunne 2010, za: Fanning 2012: 3). Te tożsamościowe przekonania nakładały się zaś na mity irlandzkiej homogeniczności, które w trakcie tworzenia się współczesnej narodowej tożsamości zrodziły się w politycznie i religijnie warunkowanym procesie wykluczania i kontestowania autentyczności oraz swojskości kolejnych grup (Fanning 2012: 30-56).

W ramach nowego irlandzkiego modernizacyjnego dyskursu narodotwórczego, w dużym stopniu celowo, wypromowano jednak wizję historycznie wielokulturowego i politycznie multikulturalistycznego społeczeństwa w okresie, gdy kolejne rządy zdawały sobie sprawę z potrzeb i konsekwencji płynących z procesu integracji z Europejską Wspólnotą Gospodarczą (EWG), a później Unią Europejską. Doświadczenia sąsiedniego Zjednoczonego Królestwa Wielkiej Brytanii oraz innych krajów zachodnich, które były zmuszone otworzyć się na imigrację, aby zaspokoić dynamicznie rosnące zapotrzebowanie na siłę roboczą, stanowiły dla władz Irlandii zestaw wzorów do naśladowania i przestróg przed popełnianiem rażących błędów. Tej wiedzy towarzyszyła manifestowana $\mathrm{w}$ narracjach czołowych polityków świadomość, że Irlandczycy sami przez wiele dekad brali w tych procesach udział, i to głównie w charakterze nisko i średnio wykwalifikowanych migrantów zarobkowych.

Relacje moich partnerów badawczych i innych osób, z którymi miałem styczność, zarówno wśród Polaków, jak i Irlandczyków, potwierdzały, że odczuwany przez większość klimat społeczny jest zgodny z intencjami twórców podwalin sukcesu gospodarczego Irlandii. Osoby, które wypowiedziały się na ten temat, uważają także, że jest to istotnie klimat korzystny dla rozwoju społecznego państwa. Polacy i Irlandczycy wyrażali przekonanie, że imigracja wpływa korzystnie na stan państwa oraz jest niezbędna dla podtrzymywania stopy wzrostu ekonomicznego i bogacenia się wszystkich mieszkańców Irlandii.

Zauważali, że migrantom jest trudniej niż rdzennym Irlandczykom podwyższać status ekonomiczno-społeczny oraz tworzyć w tym zakresie rodzaje stratyfikacji grup migranckich ze względu na kraj i środowiska pochodzenia. Najłatwiej, zdaniem większości moich rozmówców, jest migrantom z krajów anglojęzycznych, którzy nierzadko mają irlandzkie korzenie - ich sytuacja przypomina tę, w jakiej znajdują się migranci wewnętrzni, którzy muszą na nowo zorganizować swoje życie w innej miejscowości. Łatwiej niż pozostali mają też przybysze z krajów „starej Unii”, których obecność w Irlandii jest dość niewielka, ale widoczna od 
wielu dekad. Imigranci z „nowej Unii” przybyli tak licznie, że szybko stali się częścią kolorytu społecznego niemal w każdej miejscowości, ale różnice językowe oraz tendencja do tworzenia skupisk ${ }^{10}$ sprawiają, że przedstawiciele tych środowisk są wciąż postrzegani jako ciało obce. Zdaniem moich rozmówców pracownicy z tych krajów w większości przypadków awansują wolniej i wykonują gorsze zawody niż ich irlandzcy rówieśnicy, choć zazwyczaj mają lepsze formalne wykształcenie lub przygotowanie profesjonalne. Coraz więcej Irlandczyków zdaje sobie sprawę, że duża część tych nowo przybyłych pozostanie w ich kraju na zawsze, a dla dzieci wielu migrantów Irlandia będzie pierwszą ojczyzną lub wręcz jedyną, jaką będą miały. Podobnie mówi się o osobach przybywających z krajów afrykańskich (począwszy od późnych lat 80. mnionego wieku) w ramach programów dla uchodźców i akcji łączenia rodzin tudzież „zwykłej” migracji. W rozmowach ze mną najczęściej jednak unikano narracji rasistowskich, zapewne moi rozmówcy wyrażali obawy o możliwość, a niektórzy - jak w przypadku wspomnianych już rozmów o kryzysie uchodźczym - o celowość zagwarantowania im równych szans awansu społecznego i na rynku pracy.

Zrozumienie dla potrzeby otwartości rynku pracy widoczne było także w podejściu związków zawodowych do praw pracowniczych imigrantów. Nie bronią one za wszelką cenę przywilejów „rdzennych Irlandczyków”, a nastawiają się na promowanie wysokich standardów zatrudnienia, które dotyczą godnej płacy i bezpieczeństwa dla wszystkich pracowników oraz zapobiegania pracy nielegalnej i wykorzystywaniu różnic rozwoju ekonomicznego krajów pochodzenia w celu wyzyskiwania migrantów do pracy płatnej według zaniżonych stawek (tudzież wykonywanej w nieodpowiednich warunkach).

Interesujące są $\mathrm{w}$ tym kontekście obserwacje polskich migrantów z różnych miejsc pracy - większość z moich rozmówców zmieniała zawody, pracodawców oraz zarobkowała $\mathrm{w}$ wieloetnicznych zespołach pracowniczych. Jeśli chodzi o pracę niewymagającą szczególnych kwalifikacji, a przy tym relatywnie nisko płatną, zauważali oni, że zajęcia takie są zdominowane przez przyjezdnych. Właściwie wszyscy opowiadali o pojedynczych Irlandczykach zatrudnianych po znajomości na takich stanowiskach przez irlandzkich menedżerów czy majstrów. W tych opowieściach Irlandczycy nie czują odpowiedzialności za powierzoną pracę, cechują się niską motywacją i lekceważeniem obowiązków, przy czym nie okazują otwartej niechęci wobec pochodzących $\mathrm{z}$ innych krajów koleżanek i kolegów.

Wojtek, który pracował kiedyś w zakładzie produkcyjnym, opowiadał:

Przyjęli do nas takiego George’a. Jego ojciec też kiedyś pracował w tej fabryce i znał naszego majstra. Więc George przychodził do pracy, zaszywał się gdzieś i spał. Jak go majster przypilnował, to przez chwilę się starał, ale potem nam opowiadał, że tu pracuje, bo musiał coś szybko złapać,

10 Wynikająca nie tyle z cech kulturowych Polaków, ile przede wszystkim z charakteru rynku mieszkaniowego Dublina, gdzie o cenach często decyduje, jak to ujmują moi rozmówcy, „okolica”, a dopiero potem standard lokalu. 
ale myślał, że szybko znajdzie coś lepszego. [...] Po gdzieś dwóch miesiącach koleś przestał się pojawiać.

Monika, która doszła do stanowiska szefowej pięcioosobowego personelu pomocniczego w niewielkiej klinice, zwierzała się:

Na początku pracowałam z Irlandkami, byłam pierwsza z zagranicy. Ale Irlandki cały czas marudziły, nawzajem się nakręcały, że przy swoich kwalifikacjach nie powinny robić tego, a to tamtego... tu posprzątać, tam jakieś papiery pouzupełniać, i tam pretensje miały jak szef podpisał umowę z pomocą społeczną i zaczęliśmy leczyć narkomanów „na fundusz”. Ja tam oporów nie miałam, zwłaszcza że na początku jeszcze nie miałam wszystkich papierów, tylko ten podstawowy kurs, a pracę w Irlandii zaczynałam w ekipie sprzątającej, więc i tak tu było o niebo lepiej. Jak w jednym miesiącu dwie Irlandki odeszły - jedna poszła do innej kliniki, a druga nie wiem, chyba wyjechała za pracą do Stanów - to szef sam zaczął mnie cisnąć, żebym szybciej kurs skończyła i nawet mnie (tam) wysyłał w godzinach pracy.

Jednak prawie wszyscy, pytani na temat tego, jak oceniają życie i pracę w Irlandii w porównaniu z pracą w Polsce, odpowiadali w pierwszych deklaracjach, że w nowym kraju czują się lepiej. Uzasadnienia były bardzo zróżnicowane, ale w większości narracji pojawiały się stałe elementy, spośród których warto wymienić atmosferę miejsca pracy (mniejsza presja przełożonych; umiejętność pochwalenia i uprzejmego zwracania uwagi; częstsze stosowanie próśb i propozycji niż wydawanie poleceń; częstsze próby - choć zwykle jedynie kurtuazyjne - budowania relacji współpracy, a nie podrzędności służbowej; brak szantażów i nadużywania hierarchii do wyegzekwowania zobowiązań, zwłaszcza tych wykraczających poza zwykłe obowiązki służbowe przewidziane do wykonania w podstawowym czasie pracy).

Polscy migranci zwracali także uwagę na czynniki dookreślające „efekt państwa”, niezwiązane bezpośrednio z rodzajem wykonywanej pracy i ich statusem migracyjnym, lecz wynikające $\mathrm{z}$ funkcjonujących $\mathrm{w}$ Irlandii rozwiązań finansowych i podatkowych, o których często nie myśleli w momencie podejmowania decyzji o migracji, a z wielu nie zdawali sobie nawet sprawy. Większość z nich wspominała przejrzysty i przyjazny system podatkowy oraz tygodniówkę, czyli stosowany $\mathrm{w}$ wielu irlandzkich przedsiębiorstwach system wynagrodzeń tygodniowych, a nie wypłacanych co miesiąc, jak w Polsce. Uważali, że tygodniówka jest znacznie bardziej sprawiedliwa, gdyż poszczególne miesiące różnią się od siebie liczbą dni ${ }^{11}$, a przeliczanie tygodniowe ułatwia egzekwowanie wypłat za każdą godzinę zakontraktowanej pracy. Ponadto nie trzeba czekać przez cały miesiąc na kolejną pensję, co pozwala lepiej niż w Polsce planować wydatki i oszczędności.

Moi rozmówcy byli też bardzo świadomi tego, że Irlandia ustanowiła najwyższe po Luksemburgu wynagrodzenie minimalne spośród wszystkich krajów UE,

11 Kilka osób, niezależnie od siebie, wyliczało mi, że jeśli za podstawę wyliczeń weźmie się luty, który ma cztery tygodnie (a wypłata za ten miesiąc jest taka sama, jak za pozostałe), to w skali roku system wynagrodzeń miesięcznych okrada pracownika z zapłaty za około cztery tygodnie. 
które posługują się tym wskaźnikiem. Obecnie, od 1 stycznia 2018 roku, wynosi ono 9,55 EUR za godzinę i nie może być niższe niż 1614 EUR w rozliczeniu miesięcznym, co w skali rocznej daje 19368 EUR. Ze względu na obowiązujące mechanizmy dotyczące Earned Income Tax Credit efektywna kwota wolna od podatku w Irlandii w 2018 roku wynosi 16500 EUR (około 70000 PLN). Do tego dochodzą liczne ulgi, zwolnienia i dodatki (np. cotygodniowy dodatek na każde dziecko w wysokości 31,80 EUR, zwolnienia podatkowe dla osób posiadających kredyt hipoteczny). Te rozwiązania wpływają na poczucie bezpieczeństwa socjalnego i sposób racjonalizowania własnego statusu społeczno-ekonomicznego, na co nakłada się świadomość dotycząca sytuacji, w jakiej się znajdowali, gdy wyjeżdżali z kraju oraz dość aktualna wiedza na temat wynagrodzeń i podatków w Polsce. Większość osób, z którymi miałem do czynienia w trakcie moich badań, zarabia powyżej wynagrodzenia minimalnego i dodatkowo rozlicza podatki z osobą, z którą tworzy małżeństwo lub związek partnerski. U większości takich par obie osoby pracują w pełnym wymiarze czasu, a u tych, gdzie zatrudniona jest tylko jedna osoba - zazwyczaj kobieta - przebywa na urlopie lub pracuje w niepełnym wymiarze, jest to zwykle powodowane ciążą lub obowiązkami rodzicielskimi ${ }^{12}$. Stąd, choć osoby, z którymi rozmawiałem, nie uznają za wysoki swojego statusu społeczno-ekonomicznego w Irlandii i wyrażają często przekonanie, że gdyby były Irlandczykami, miałyby szanse na jeszcze lepsze pozycje zawodowe i wyższe zarobki, starają się one czerpać satysfakcję z tego co osiągnęły, w czym pomagają im wiedza i przekonania na temat sytuacji w kraju, z którego wyjechały.

12 Oczywiście, są osoby czy rodziny, które oceniają swoją sytuację bytową krytycznie. Ma to podłoże nie tylko materialne, choć we wszystkich przypadkach, które poznałem, osoby, lub osoby i partnerzy jednocześnie, wykonywały zajęcia, które oceniały jako ciężkie i mało prestiżowe, wręcz niedoceniane: porządkowe lub opiekunów w instytucjach opieki społecznej. W jednej sytuacji małżeństwo osób wykonujących relatywnie nisko płatne prace porządkowe (za to umiejętnie rozplanowane - na kilku umowach, w instytucjach, które umożliwiały łączenie pracy na etat i samozatrudnienie oraz wykonywanie dodatkowo płatnych zleceń) długo spierało się o to, czy wracać do Polski - ona nie chciała, jemu bardzo zależało - i zgodnie przyznawali, że nie są zadowoleni ze statusu społecznego w Irlandii, choć uznawali, że osiągnęli bardzo wiele: kupili i spłacili mieszkanie, wykształcili dzieci. Ona twierdziła, że po tylu latach wyrzeczeń (11 w momencie gdy ich poznałem - wyjechali do Polski dwa lata później), teraz może w końcu godnie zarabiać na własne potrzeby i „czuć się dobrze”, a po powrocie do Polski nie będzie miała takiej szansy ze względu na niemożliwość znalezienia dobrze płatnego zajęcia. On nieustannie wyliczał, na jaki poziom życia byłoby ich stać, gdyby sprzedali wszystko i sami, bez dzieci wrócili do Polski. Ostatecznie przekonał żonę i obecnie mieszkają w Polsce, gdzie kupili dom i podjęli pracę w nowych zawodach (przedszkolanka i kierowca: „żeby coś robić i płacić ZUS); posiadają też prawo do irlandzkiej emerytury. 


\section{Odbiór Polski - doświadczenia, wyobrażenia i retrospektywne racjonalizacje: wytwarzanie pamięci migracyjnej}

Polscy migranci w Dublinie śledzą sytuację w Polsce. Mają wiedzę na jej temat $\mathrm{z}$ mediów społecznościowych, portali informacyjnych, z częstych rozmów telefonicznych i internetowych $\mathrm{z}$ rodziną i znajomymi, którzy pozostali w kraju lub mają stamtąd aktualne informacje. Wielu $\mathrm{z}$ nich co najmniej raz $\mathrm{w}$ roku odwiedza Polskę i spędza tam od kilku dni do kilku tygodni. W pewnym transnarodowym sensie Polska stanowi dla nich bezpośredni kontekst porównawczy, nieustannie przypominając skąd wyjechali, co pozostawili, czego uniknęli. Posiadają wciąż żywe wspomnienia okresu swego dorastania i młodości, szkoły i studiów, pierwszych doświadczeń na rynku pracy, odczuć dotyczących klimatu społecznego i politycznego w kraju i w lokalnych społecznościach, z których się wywodzą, bądź poznanych w trakcie migracji wewnątrzpolskich, bardzo częstych wśród moich rozmówców i partnerów badawczych. Obecnie ich opinia o Polsce ulega dodatkowemu filtrowaniu przez doświadczenia irlandzkie. Jest to rodzaj sprzężenia zwrotnego, w którym doświadczenia, wyobrażenia o rzeczywistości przekładają się na retrospektywne racjonalizacje polegające na nakładaniu wydarzeń i poglądów obecnych na wydarzenia z przeszłości oraz na tłumaczeniu nimi stanu obecnego.

Pamięć migracyjna ulega przeobrażeniom związanym $\mathrm{z}$ ciągłym uzupełnianiem wiedzy migrantów, którzy uczą się także nowych sposobów pozyskiwania informacji i interpretowania faktów społecznych, w tym wyobrażeń. Dokonują często swoistej generalizacji, w której ramy wchodzą odczucia i wyjaśnienia odnośnie do sytuacji finansowej, statusu społecznego, aspiracji i możliwości ich realizacji, sytuacji społeczno-obyczajowej (im bardziej tego rodzaju tematy nabrzmiewają w nowym kraju, tym częściej stają się elementem porównań wobec ojczyzny, choćby nawet nie miały dla migrantów większego znaczenia w momencie wyjazdu), efektu państwa. Tym samym ten przywoływany klimat społeczny Polski z momentu wyjazdu ulega nakładaniu na obecne wyobrażenia o klimacie Polski.

Jako przykład takiej sytuacji niech posłuży tu kwestia zarobków. Za punkt wyjścia porównań migranci przyjmują swoją, a czasem cudzą lub tę uznawaną przez poszczególne osoby za powszechną, sytuację ekonomiczną z okresu, gdy podejmowały decyzję o wyjeździe. Wiedza początkowa i porównawcze obserwacje sytuacji zarobkowej prowadzone przez cały okres pobytu na emigracji pozwalają im na relacyjną ocenę wysokości dochodów i zgromadzonych oszczędności, kosztów życia i interesujących ich produktów czy posiadanych zobowiązań finansowych w tych krajach, a przy tym wpływają bezpośrednio na proces podejmowania decyzji o tym, czy wracać do Polski.

Od stycznia 2019 roku w Polsce wzrosło o 7,1\% wynagrodzenie minimalne, osiągając 2250 zł brutto miesięcznie (przy 12 wypłatach miesięcznych to 27000 PLN 
w skali rocznej). Stawka godzinowa dla pracujących na umowach cywilnoprawnych wynosi 14,70 zł (wzrost o 7,3\%). Minimalna płaca w Irlandii wynosi $1614 €$ miesięcznie (ok. 7000 PLN), to jest, przy 12 wypłatach miesięcznych 19368 EUR rocznie, co oznacza poziom wynagrodzenia, który w Polsce osiąga mniej niż $20 \%$ zatrudnionych (Frączyk 2019). Wynagrodzenie minimalne w Polsce to obecnie około 32\% irlandzkiego, a w okresie podejmowania przez większość moich rozmówców decyzji o migracji, w latach 2005-2007, było to od około 16 do $18 \%$. $\mathrm{W}$ odniesieniu do siły nabywczej i inflacji w obu krajach nie jest to wystarczająca zachęta do powrotu dla osób, z którymi rozmawiałem. Oczywiście biorą one pod uwagę wiele innych czynników związanych ze sferą dobrostanu, które kształtują ich indywidualne oceny i wyobrażenia na rozmaite sposoby.

Klimat społeczny Polski jest przez nich poddawany rozmaitym interpretacjom. Efekt państwa jako rezultat „przyziemnych procesów organizacji przestrzennej, układów czasowych, specyfikacji funkcjonalnych, nadzoru i inwigilacji oraz reprezentacji” (Mitchel 1999: 185), zwłaszcza u osób, które śledzą wiadomości z Polski, wytwarza u nich przekonanie, że pomimo znacznego rozwoju infrastruktury i olbrzymich nakładów finansowych zwiększonych jeszcze przez polityki spójnościowe i celowe fundusze UE, wciąż nie udało się zasypać różnic dochodowych i mentalnościowych między Polską a Zachodem (którego wyobrażenia kształtuje życie w określonym kraju na migracji i żywe kontakty z osobami, głównie rówieśnikami, którzy wyemigrowali do innych krajów rozwiniętych).

We wspomnieniach kilku osób, które przed opuszczeniem Polski zdobyły tam wysoką pozycję zawodową - w grupie, $\mathrm{z}$ którą nawiązałem kontakty badawcze, byli to głównie lekarze lub dentyści - pojawia się bardzo emocjonalny wątek wskazywania bezpośrednich i pośrednich sprawców sytuacji, która popchnęła je do ostatecznego wyjazdu do Irlandii. Lekarze emigrowali zazwyczaj stopniowo, najpierw przyjeżdżając na krótkoterminowe kontrakty do polskich przychodni, rzadziej do placówek prowadzonych przez Irlandczyków lub irlandzkie instytucje. Kontynuowali w tym czasie praktyki w Polsce. W ich uzasadnieniach decyzji migracyjnych nad aspektami finansowymi przeważa wątek osobistego przeżywania frustrującej, złej organizacji służby zdrowia w Polsce, która wymagała od nich wykonywania obowiązków kosztem życia prywatnego, w przypadku kilku osób, pracy $\mathrm{w}$ wielu miejscach jednocześnie, a także zmagań $\mathrm{z}$ administracją i przerostem biurokratycznych formalności.

Dla prawie wszystkich lekarzy bardzo istotną, jeśli nie najważniejszą, kwestią był odczuwany przez nich upadek autorytetu ich zawodu wywołany z jednej strony przez uczestników kultury publicznej - media i polityków, nieustannie atakujących wszelkie "prawdziwe i wymyślone” błędy lekarskie i stosujących za nie odpowiedzialność zbiorową oraz oskarżanie całej grupy o korupcję i świadome doprowadzanie do zapaści państwowej służby zdrowia po to, by czerpać profity z praktyk prywatnych. Za szczególnie niesprawiedliwe i haniebne, moi rozmówcy uważali wypowiedzi rządzących w latach 2005-2007 i z pamięci cytowali Ludwika 
Dorna („pokaż lekarzu, co masz w garażu”, „wziąć lekarzy w kamasze”) czy Zbigniewa Ziobro (,już nikt nigdy przez tego pana pozbawiony życia nie będzie”). Przywołują też aktualne przykłady nieuczciwej dyskursywnej walki polityków ze środowiskiem lekarskim oraz tej toczącej się w obszarze służby zdrowia i opieki nad chorymi i niepełnosprawnymi. Tu opisują reakcję polityków rządzącej w latach 2015-2019 koalicji na protesty lekarzy rezydentów, rodziców niepełnosprawnych dzieci oraz zorganizowaną w roku 2019 kampanię „Polska to chory kraj”. Wiele wypowiedzi polskich lekarzy działających w Irlandii wskazuje, że dla tej grupy to właśnie efekt państwa odegrał decydującą rolę w ich decyzji, by wyjechać z Polski na stałe, gdyż to zła organizacja systemu i manipulacje w sferze wyobrażeń społecznych uniemożliwiały im odczuwanie dobrostanu, uzyskanie poczucia satysfakcji życiowej. Podobnie do motywów swoich decyzji o emigracji odnoszą się osoby, które zrezygnowały z kariery akademickiej w Polsce lub też pracowały w niej jako nauczyciele, choć w ich wypowiedziach większy nacisk kładziony jest na upadek etosu naukowca, czy nauczyciela związany z systemową pauperyzacją tych grup zawodowych i niezwykle długim czasem dochodzenia w zawodach oświatowych i akademickich do samodzielności życiowej i profesjonalnej.

Wyobrażenia na temat dobrostanu wynikają z osobistych doświadczeń i zapatrywań. Wspomnienia doświadczeń i odczuwanych emocji również podlegają retrospektywnym racjonalizacjom, do których impulsem bywają wydarzenia czy doznania, które miały miejsce w późniejszym czasie. Polskie migracje do Irlandii mają na ogół charakter transnarodowy. Również moi rozmówcy, których „centrum życiowe" ${ }^{\prime 3}$ osadzone jest w nowym społeczeństwie, są jednocześnie wciąż - w dość znacznym stopniu - osadzeni w kontekście polskim, co pozwala im relatywizować ich sytuację w Irlandii, a to z kolei wpływa na łatwiejszą adaptację do zmiennej sytuacji w nowym kraju. Gdy na przykład ktoś jest zmuszony do zmiany pracy na gorzej płatną, to może sobie tłumaczyć, że nawet owa gorsza posada jest o wiele lepiej płatna niż ta, która byłaby dostępna w Polsce.

Tak o sobie opowiadała Agata, która pracowała na etacie w hospitality services (nie ma dobrego odpowiednika w tłumaczeniu na polski, de facto należałoby użyć wieloznacznego określenia „w obsłudze”) pewnego dublińskiego uniwersytetu. W czasach kryzysu gospodarczego w 2009 roku, jak to określiła, „zaoutsorsowano ją". Zwolniono ją wraz z całym działem. Zaproponowano jej jednak, w uznaniu jej kompetencji i dotychczasowej postawy, gorzej płatną i mniej prestiżową posadę w firmie ochraniającej ten sam kampus, która przejęła również część zadań rozwiązanego działu. Przyjęła tę sytuację z bólem, lecz wytłumaczyła sobie, że za wcześnie, by wracać do Polski, bo za kilka lat uzyska prawo do irlandzkich świadczeń emerytalnych, a poza tym robi to, na czym się już zna, w miejscu, które zna. Nadmieniła, że poczuła niechęć na myśl, że miałaby wrócić do swojej miejscowości w Polsce, gdzie pewnie otoczenie dawałoby jej do zrozumienia, że sobie nie

13 Wyrażenie zapożyczone z Ustawy o podatku dochodowym od osób fizycznych (art. 3.1a pkt1), w którym określono, kogo uważa się za osobę zamieszkującą na terytorium Polski. 
poradziła na emigracji oraz musiałaby podjąć pracę w jakimś nieciekawym miejscu, lub w szkole, z której zrezygnowała. Nie rozważała poszukiwań innej pracy ze względu na panujący wtedy kryzys ekonomiczny w Irlandii, który spowodował, iż uznała, że lepsza stabilna praca tam, gdzie ją doceniają, niż nowy start w zupełnie nowym miejscu. Agata tak to podsumowała:

Tak samo zrobiło kilkoro moich polskich kolegów i wszyscy na tym dobrze wyszliśmy. Gdy kryzys się skończył, uczelnia uznała, że pomimo przykrej sytuacji nie obraziliśmy się, tylko robiliśmy swoje i przez to pokazaliśmy swoją wartość i lojalność. Gdy pojawiały się wakaty na naszym uniwersytecie - w administracji czy odtwarzanym hospitality, albo jakieś posady techniczne, to my mieliśmy pierwszeństwo. Wszyscy znów pracujemy na etatach uniwersyteckich, niektórzy mają znacznie lepsze funkcje niż przed zwolnieniami. Kilka dziewczyn porobiło studia i kursy, i teraz pracują w biurach, jeden kolega kończy doktorat i jest kierownikiem działu obsługi na naszym innym kampusie. Opłacało się zagryźć zęby. Teraz nas bardziej szanują.

Wątek ten wskazuje, że kooperacja i dyskusje wewnątrzgrupowe pozwalają wypracować wspólne racjonalizacje, co w opisywanym przypadku pomogło złagodzić emocjonalne skutki niefortunnej sytuacji i zapobiec pogorszeniu samooceny.

Interesującym aspektem transnarodowego życia, w którym migranci mniej martwią się o swoją sytuację w nowym państwie, do którego żywią dość duży stopień zaufania, a wciąż czują się odpowiedzialni za kraj pochodzenia, widząc tam potrzebę głębokich zmian, jest kwestia zaangażowania wyborczego. Jak wspomniałem, jest ono niewielkie w odniesieniu do wyborów lokalnych, w których polscy migranci mogą brać udział bez posiadania obywatelstwa Irlandii (zob. też Lesińska, Kloc-Nowak, Pszczółkowska 2019). Jednak rośnie ono w specyficzny sposób, jeśli chodzi o wybory parlamentarne w Polsce.

Kiedy weźmie się pod uwagę liczbę osób figurujących jako Polacy w irlandzkich wykazach spisowych, ich udział w wyborach do polskiego parlamentu wydaje się niewielki. W publikacjach spisowych z 2002 roku Polacy nie są wyodrębniani jako osobna grupa. Wchodzą w skład liczącej 8335 osób grupy wykazanej jako „other Europe” obejmującej obywateli 19 państw nienależących wówczas do UE. W pierwszym spisie powszechnym przeprowadzonym po rozszerzeniu UE z 2004 roku, a który odbył się w roku 2006, liczba Polaków rezydujących w Irlandii została oszacowana na 63276 osób (w tym 22988 kobiet i 40288 mężczyzn) zamieszkujących w całym kraju. Do list wyborców na odbywające się w tym okresie wybory parlamentarne 2005 i 2007, zapisano w całej Irlandii odpowiednio - 1231 i aż 21333 wyborców. Głosy oddało w 2005 roku - 885 osób (71,89\% uprawnionych), a w 2007 roku - 14011 (65,68\% uprawnionych).

Dopiero po spisach powszechnych z lat 2011 i 2016 irlandzkie Central Statistic Office (CSO B0439, CSO BDR26, CSO C0437, CSO E7002, CSO E7013) opublikowało bazy danych pozwalające ocenić liczbę migrantów z Polski zamieszkujących poszczególne hrabstwa i prowincje. Ze spisu powszechnego z 2011 roku wynika, że w całej Irlandii zamieszkiwało 122585 osób opisywanych jako Polacy 
(59203 kobiety i 63382 mężczyzn), z których do obejmującej Dublin prowincji Leinster przypisano 68198 osób (32937 kobiet i 33733 mężczyzn). Z kolei w spisie z 2016 roku figuruje 122515 Polaków w Irlandii (60655 kobiet i 61860 mężczyzn), z czego w prowincji Leinster - 67916 (33733 kobiety i 34183 mężczyzn). Pamiętać jednak należy, że rośnie liczba osób, które posiadają jednocześnie obywatelstwo irlandzkie i polskie. Z szacunków opartych na danych z CSU wynika, że z tej grupy 9273 osób uwzględnionych dopiero w spisie z 2016 roku 6530 osób urodziło się w Irlandii, 2743 w Polsce i innych państwach, a tylko ok. 2480 osób miało 18 i więcej lat. Zatem większość $\mathrm{z}$ nich to dzieci i młodzież.

Jeśli chodzi o komisje wyborcze udostępnione dla ludności polskiej zamieszkującej prowincję, to $\mathrm{z}$ danych Państwowej Komisji Wyborczej dotyczących wyborów do parlamentu, wynika, że liczby głosujących w lokalach w Dublinie kształtowały się w następujący sposób:

\begin{tabular}{|l|l|l|l|l|l|}
\hline $\begin{array}{l}\text { Wybory do } \\
\text { Sejmu RP } \\
\text { w Dublinie }\end{array}$ & $\begin{array}{l}\text { Liczba } \\
\text { Polaków } \\
\text { w wieku } \\
\text { wyborczym } \\
\text { czynnym } \\
\text { w prowincji } \\
\text { Leinster po } \\
\text { 2011 roku }\end{array}$ & $\begin{array}{l}\text { Liczba zare- } \\
\text { jestrowanych } \\
\text { wyborców }\end{array}$ & $\begin{array}{l}\text { Liczba pobra- } \\
\text { nych kart do } \\
\text { głosowania }\end{array}$ & $\begin{array}{l}\text { Frekwencja } \\
\text { wg PKW }\end{array}$ & $\begin{array}{l}\text { Frekwencja } \\
\text { względem } \\
\text { szacowa- } \\
\text { nej liczby } \\
\text { Polaków } \\
\text { w wieku } \\
\text { wyborczym }\end{array}$ \\
\hline 2005 & Brak danych & 1231 & 885 & $71,89 \%$ & b.d. \\
\hline 2007 & Brak danych & 14619 & 9078 & $62,62 \%$ & b.d. \\
\hline 2011 & 69294 & 6261 & 5363 & $85,66 \%$ & $7,74 \%$ \\
\hline 2015 & ok. 69043 & 7671 & 6504 & $84,79 \%$ & $9,42 \%$ \\
\hline 2019 & Ok. 69000 & 8685 & 8009 & $92,22 \%$ & $11,5 \%$ \\
\hline
\end{tabular}

Wyniki te są oczywiście przybliżone. Liczbę Polaków w wieku wyborczym czynnym oszacowałem na podstawie bazy CSU pt. „Population Usually Resident and Present in the State 2011 to 2016 (Number) by Nationality, Age Group, County of Usual Residence and Census Year" (CSO E7002). W bazie tej utworzono kategorię wiekową „15-24 years”, przez co musiałem nieco upraszczająco przyjąć, że ok. 70\% tej grupy 10 roczników, to osoby powyżej 18. roku życia.

Szacowana w podobny, uproszczony sposób liczba Polaków w wieku wyborczym w Irlandii, to 96674 osoby w 2011 roku oraz 99360 w roku 2016. W ten sposób możemy ostrożnie przyjąć, że procentowy udział pełnoletnich migrantów z Polski w wyborach parlamentarnych (na podstawie zestawienia danych spisowych i frekwencji mierzonej przez PKW [2015; 2019]) kształtował się dla wyborów w latach 2015 i 2019 w przybliżony poniżej sposób: 


\begin{tabular}{|l|l|l|l|l|l|}
\hline $\begin{array}{l}\text { Wybory do } \\
\text { Ssejmu RP } \\
\text { w Irlandii } \\
\text { w latach 2015 } \\
\text { i } 2019\end{array}$ & $\begin{array}{l}\text { Liczba } \\
\text { Polaków } \\
\text { w wieku } \\
\text { wyborczym } \\
\text { czynnym } \\
\text { w Irlandii po } \\
\text { 2011 roku }\end{array}$ & $\begin{array}{l}\text { Liczba zare- } \\
\text { jestrowanych } \\
\text { wyborców }\end{array}$ & $\begin{array}{l}\text { Liczba pobra- } \\
\text { nych kart do } \\
\text { głosowania }\end{array}$ & $\begin{array}{l}\text { Frekwencja } \\
\text { wg PKW }\end{array}$ & $\begin{array}{l}\text { Frekwencja } \\
\text { względem } \\
\text { szacowanej } \\
\text { liczby Polakw } \\
\text { w wieku wy- } \\
\text { borczym }\end{array}$ \\
\hline 2015 & ok. 99360 & 10469 & 9000 & $85,97 \%$ & $9,06 \%$ \\
\hline 2019 & ok. 99360 & 14665 & 13264 & $90,41 \%$ & $13,35 \%$ \\
\hline
\end{tabular}

\section{Podsumowanie}

Polscy migranci w Dublinie należący do interesującej mnie grupy tych, którzy nie planują wrócić do Polski w dającym się przewidzieć okresie czasu, doszukują się przyczyn tego stanu rzeczy w dobrostanie, któremu sprzyja pozytywnie odbierany irlandzki klimat społeczny. Byliby gotowi wrócić do Polski, gdyby uznali, że sytuacja w ojczystym kraju zmieniła się na korzyść w sposób umożliwiający poczucie podobnego rodzaju dobrostanu jak na emigracji. Wymagane w tym ujęciu zmiany dotyczą sprawności sfery regulowanej przez działalność państwa i administracji oraz klimatu społecznego. Te sfery, które wzajemnie się przenikają i kształtują, w deklaracjach moich rozmówców i partnerów wydają się ważniejsze niż bardzo istotny czynnik ekonomiczny, gdyż określają perspektywy trwałości dobrostanu. Można odczuwać satysfakcję i szczęście przy posiadaniu relatywnie skromnych zasobów materialnych, jeśli klimat społeczny i infrastruktura administracyjno-polityczna wytwarzają poczucie możliwości sukcesywnego dążenia do zaspokajania aspiracji (zob. Kaczmarek 2017).

Wpływ na to ma sposób, w jaki postrzegają porównawczo efekt państwa w Irlandii oraz w Polsce. Ze względu na to, że w Irlandii „żyje im się lepiej”, nie konstruują silnego podziału między irlandzkim państwem a społeczeństwem, który wciąż występuje $\mathrm{w}$ ich relacjach na temat Polski. Opisując własne relacje z Irlandią, traktują tamto państwo i społeczeństwo jako nierozerwalnie sprzężone elementy jednego układu. Ma to emocjonalne znaczenie dla osób starających się podchodzić refleksyjnie do swojej sytuacji migracyjnej. Michał, jeden z polskich prawników działających w Irlandii ujął to tak:

Posłałem dzieci do irlandzkiej, dobrej szkoły prywatnej żeby się integrowały, żeby miały irlandzkich przyjaciół i łatwiejszy start niż ja. Żeby szybciej nauczyły się brać sprawy w swoje ręce i czuły, to co ja zrozumiałem, gdy w końcu poczułem, dlaczego tu mi lepiej, dlaczego tu zostaję: tu i w Polsce jest demokracja, ale to tu się czuję suwerenny, a w Polsce wciąż jestem poddanym. To relacje międzyludzkie tak działają, tu nawet jak jesteś znikąd, to cię wysłuchają, obsłużą, pożartują z tobą. To może i jest powierzchowne, ale dobrze działa na samopoczucie. W Polsce to zależy, jak trafisz - może być super, bo trafisz na superludzi, ale może być i tak, że bez przyczyny cię gnoją. A najgorzej jak cię gnoją w szkole, w pracy, w urzędzie, w sklepie, tylko dlatego, że 
mogą, bo otrzymali odrobinę władzy. Może o to chodzi - w Irlandii czują niechęć do nadużywania władzy. Przynajmniej w stosunkach międzyludzkich ${ }^{14}$.

Jego głos nie jest odosobniony. Można wręcz powiedzieć, że to opinia reprezentatywna dla grupy moich badawczych znajomych i partnerów. Polscy prawnicy działający w Irlandii mają jednak dostęp do dziesiątek spraw dotyczących obywateli i żyjących tam migrantów, na podstawie których snują analizy porównawcze dotyczące stopnia opresyjności/przyjazności irlandzkiego i polskiego systemu prawnego i administracyjnego wobec obywatela. Podkreślają, że tym, co ujmuje wielu Polaków, jest „Zaufanie wobec interesanta tak długo, dopóki nie ma dowodów, że nie zasługuje na nie" i relatywnie mniejsza biurokracja. Innym wrażeniem płynącym z porównań działania instytucji na płaszczyźnie oddolnego kontaktu $\mathrm{z}$ „interesantem” jest to, że „tu [w Irlandii] urzędnik patrzy, czy może pomóc, nie traktuje tego jako łaski czy osobistego poświęcenia, nie czeka na dozgonną wdzięczność i uwielbienie tylko za to, że wykonał swoją pracę. [...] Nie doniosłam jakiegoś dokumentu, a oni tylko się śmiali, że to ja robię z tego problem, bo przecież mogę napisać oświadczenie. Innym razem po prostu dosłałam pocztą" (Aneta w opowieści o tym, jak załatwiała obywatelstwo dla córki).

Wyobrażenia na temat państwa przyjmującego i odbiór panującego tam klimatu społecznego wpływają na decyzje tych migrantów z Polski - na tym etapie migracji, na którym są teraz, po dziesięciu, piętnastu latach od wyjazdu - przez porównanie $\mathrm{z}$ wciąż aktualizowanymi wyobrażeniami na temat państwa i klimatu społecznego ojczyzny. Żadna z osób, z którymi rozmawiałem, nie odrzuca kategorycznie idei powrotu, większość jednak przytacza więcej argumentów za tym, by pozostać w Irlandii lub emigrować do jeszcze innego państwa, niż za tym, by wracać do Polski. Poczucie, że w Irlandii państwo i społeczeństwo stanowią części jednej całości, w przeciwieństwie do Polski, gdzie wciąż czują podział na władzę i społeczeństwo, może być w znacznym stopniu rezultatem wyuczonych sposobów odnoszenia się do państwa w Polsce, i - z drugiej strony - faktu, że co najmniej początkowo, w Irlandii wszystko wydawało się bardziej obce i abstrakcyjne. Upływ lat nie łagodzi jednak tego dysonansu u osób, które w Irlandii osiągnęły relatywnie satysfakcjonującą pozycję i dla których powrót do Polski wydaje się większym ryzykiem niż wyjazd do Irlandii w momencie, gdy podejmowały swe decyzje migracyjne, a także aniżeli pozostanie w nowym kraju, w którym zainwestowali bardzo istotny okres swojego dorosłego życia.

14 Dopytany, co rozumie przez gnojenie, odparł, że „niewymuszoną nieuprzejmość, bezinteresowne chamstwo, manifestowanie znaczenia i brak antycypacji, że role się mogą odwrócić, i to w najmniej oczekiwanej sytuacji”. 


\section{Bibliografia}

Bache I., Scott K. (red.)

2018 The Politics of Well-being: Theory, Policy and Practice, London-New York.

Basch L., Glick Schiller N., Blanc-Szanton C.

1994 Nations Unbound: Transnational Projects, Postcolonial Predicaments and Deterritorialized Nation-States, New York.

Blim M.

2005 Equality and Economy: The Global Challenge, Walnut Creek, CA.

Corsín Jiménez A.

2007, Well-being in Anthropological Balance: Remarks on Proportionality as Political Imagination, w: A. Corsín Jiménez (red.), Culture and Well-Being: Anthropological Approaches to Freedom and Political Ethics, London, s. 180-197.

CSO [Central Statistics Office]

2002 B0439: 2002 Population Usually Resident and Present in their Usual Residence by Sex, Nationality, Usual Residence and CensusYear.

CSO [Central Statistics Office]

2002 BDR 26: 2002 Population Usually Resident and Present in the State by Sex, Nationality and CensusYear.

CSO [Central Statistics Office]

2019C0437: Population Usually Resident and Present in the State by Sex, Birthplace, Nationality and CensusYear.

CSO [Central Statistics Office]

2019E7013: Population Usually Resident and Present in the State 2011 to 2016 by Age Group, Sex, Nationality and CensusYear (2011-2016)

CSO [Central Statistics Office]

2019E7002: Population Usually Resident and Present in the State 2011 to 2016 by Nationality, CensusYear, Sex and County of Usual Residence (2011-2016)

Clark D.

2002 Visions of Development: A Study of Human Values, Cheltenham.

Coen C., Maguire M.

2012 Death of a Tiger: The Collapse of Irish Property Dreams, „Anthropological Notebooks", nr 18 (1), s. 5-22.

Coulter C., Coleman S.

2003 The End of Irish History? Critical Reflections on the Celtic Tiger, Manchester.

Crisp R., Hooker B. (red.)

2000 Well-being and Morality: Essays in Honour of James Griffin, Oxford.

Cummins R.A.

2005 Measuring Health and Subjective Well-being: Vale, Quality-adjusted Life-years, w: L. Manderson (red.), Rethinking Well-being, Perth, s. 69-90.

Czapiński J.

1992 Psychologia szczęścia. Przeglad badań i zarys teorii cebulowej, Poznań.

Dasgupta P.

1993 An Inquiry into Well-being and Destitution, Oxford.

2001 Human Well-being and the Natural Environment, Oxford.

Diener E.

1984 Subjective Well-being, „Psychological Bulletin”, nr 95, s. 542-575. 
Diener E., Fujita F.

1997 Social Comparisons and Subjective Well-being, w: F. Fujita, B.P. Bunk, F.X. Gibbons (red.), Health, Coping, and Well-being: Perspectives from Social Comparison Theory, London, s. 329-357.

Dunne T.

2010 Rebellions: Memoir, Memory and 1798, Dublin.

Fanning B.

2011 Immigration and Social Cohesion in the Republic of Ireland, Manchester.

2012 Racism and Social Change in the Republic of Ireland, Manchester.

Fechter M.

2007 Living in a Bubble: Expatriate's Transnational Spaces, w: V. Amit (red.), Going First Class? New Approaches Towards Privileged Travel and Movement, New York-Oxford, s. 33-52.

Fiech M., Mudyń K.

2011 Pomijanie działań kształtujących poziom zadowolenia zawodowego pracowników jako przejaw dysfunkcji w procesie zarządzania zasobami ludzkimi, „Problemy Zarządzania", vol. 9, nr 4 (34), s. 147-161.

Fischer E.F.

2014 The Good Life: Aspiration, Dignity, and the Anthropology of Well-being, Stanford. Frączyk J.

2019 „Gonimy Europe w płacy minimalnej”. Ministerstwo trochę przesadziło, https://www.money.pl/gospodarka/gonimy-europe-w-placy-minimalnej-ministerstwo-troche-przesadzilo-6333494132983937a.html (dostęp: 25.04.2019).

Gough I., McGregor J.A., Camfield L.

2007 Theorising Well-being in International Development, w: I. Gough, J.A. McGregor (red.), Well-being in Developing Countries: From Theory to Research, Cambridge, s. $3-43$.

Griffin J.

1986 Well-being: Its Meaning, Measurement and Moral Importance, Oxford.

Grřnseth A.S.

2013 Introduction, w: A.S. Grřnseth (red.), Being Human, Being Migrant: Senses of Self and Well-being, London-New York, s. 1-26.

Gudeman S.

1986 Economics as Culture, London.

Gupta A.

2006 Blurred Boundaries: The Discourse of Corruption, the Culture of Politics, and the Imagined State, w: A. Sharma, A. Gupta (red.), The Anthropology of the State: A Reader, Oxford, s. 211-242.

Hann C.M. (red.)

1998 Property Relations: Renewing the Anthropological Tradition, Cambridge.

Horolets A.

2015 Finding One's Way: Recreational Mobility of Post-2004 Polish Migrants in the West Midlands, UK, „Leisure Studies”, vol. 34 (1), s. 5-18.

Jaskułowski K.

2019 The Everyday Politics of Migration Crisis in Poland: Between Nationalism, Fear and Empathy, London-New York. 


\section{Kaczmarek Ł.}

2012 Wolny przepływ towarów i (u)sług. Multikulturalizm a wielokulturowość w wyobrażeniach o swojskości i przydatności społecznej oraz legitymizacji kulturowej $w$ kontekście aksjologii ekonomicznej, „Pogranicze. Studia Społeczne”, nr 20, s. 107-131.

2017 Aspiracje i stabilizacja. Status społeczny i dobrostan polskich migrantów w Dublinie, „Zeszyty Etnologii Wrocławskiej”, nr 26, s. 47-68.

Khan M.H.

2005 What Is a „Good Investment Climate”?, w: G. Kochendörfer-Lucius, B. Pleskovic (red.), Investment Climate, Growth, and Poverty, Washington, s. 77-86.

Kloc-Nowak W.

2017 Zapuszczanie korzeni na Zielonej Wyspie? Polacy w Irlandii w drugiej dekadzie po akcesji do UE, CMR Working Papers, no. 104/162.

Komter A.E.

2005 Social Solidarity and the Gift, Cambridge.

Kuhling C., Keohane K.

2007 Cosmopolitan Ireland: Globalisation and Quality of Life, London-Dublin-Ann Arbor, MI.

Laidlaw J.

2000 A Free Gift Makes No Friends, „Journal of the Royal Anthropological Institute”, nr 6, s. 617-634.

Lesińska M.

2017 Analiza udziału Polaków w Irlandii w wyborach polskich w latach 1990-2015, CMR Working Papers, no. 105/163.

Lesińska M., Kloc-Nowak W., Pszczółkowska D.

2019 Between Poland and Ireland: Political and Public Participation of Migrants in a Transnational Social Space, „CMR Spotlight: Center of Migration Research Newsletter", no. 1 (8), January.

Mitchell T.

1999 Society, Economy, and the State Effect, w: G. Steinmetz (red.), State/Culture: State-Formation after the Cultural Turn, s. 76-97.

Mühlau P., M. Kaliszewska, A. Röder

2011 Polonia in Dublin, Preliminary Report of Survey Findings, Report No.1, Trinity College Dublin, Trinity Immigration Initiative, Parallel Societies or Overlapping Identities Project.

PKW [Państwowa Komisja Wyborcza]

2015 https://parlament2015.pkw.gov.pl/350/Wyniki/Sejm/zagranica/0/38.html (dostęp: 4.06.2019).

PKW [Państwowa Komisja Wyborcza]

2019 https://wybory.gov.pl/sejmsenat2019/pl/frekwencja/Koniec/sejm/gm/372 (dostęp: 4.06.2019).

Ryff C.D.

1989 Happiness Is Everything, or Is It? Explorations on the Meaning of Psychological

Well-being „Journal of Personality and Social Psychology”, vol. 57, no. 6, s. 1069-1081. Ryff C.D., Keyes C.M.

1995 The Structure of Psychological Well-being Revisited, „Journal of Personality and Social Psychology", vol. 69, no. 4, s. 719-727.

Said E.W.

1991 Orientalizm, przeł. W. Kalinowski, Warszawa. 
Seligman M.

2003 Authentic Happiness, London.

Sen A.

1980 Equality of What?, w: S. McMurrin (red.), Tanner Lectures on Human Values, vol. 1, Cambridge.

1993 Capability and Well-being, w: M.C. Nussbaum, A. Sen (red.), The Quality of Life, Oxford.

Sharma A., Gupta A.

2006 Introduction, w: A. Sharma, A. Gupta (red.), The Anthropology of the State: A Reader, Oxford, s. 1-42.

Sumner L.W.

1996 Welfare, Happiness, and Ethics, Oxford.

Taussig M.T.

1997 The Magic of the State, New York-London.

Thin N.

2005 Happiness and the Sad Topics of Anthropology, „WeD” [Well-being in Developing Countries], Working Paper 10, URL (consulted May 2007), http://www.bath.ac.uk/ econ-dev/wellbeing/research/workingpaperpdf/wed10.pdf.

UNDP [United Nations Development Programme]

1990 Human Development Report, New York-Oxford.

1994 Human Development Report, New York-Oxford.

1998 Human Development Report, New York-Oxford.

2002 Human Development Report, New York-Oxford.

Ustawa z dnia 26 lipca 1991 r. o podatku dochodowym od osób fizycznych, Dz.U. 1991 nr 80, poz. 350 z późn. zmian., t.j. Dz.U. 2019, poz. 1387.

Verdery K., Humphrey C. (red.)

2004 Property in Question: Value Transformation in the Global Economy, Oxford-New York.

Wilson T.D.

1994 What Determines Where Transnational Labor Migrants Go? Modifications in Migration Theories, „Human Organization”, vol. 53, no. 3, Fall.

Wilson T.M., Donnan H.

2006 The Anthropology of Ireland, Oxford-New York.

Wright $\mathrm{K}$.

2012 International Migration, Development and Well-being, London-New York. 